\title{
Planting rosewood for the sustainable essential oil production: Influence of surrounding forest and seed provenance on tree growth and essential oil yield
}

Nadine AmUSANT ${ }^{1}$ Alexis DIGEon ${ }^{1}$ Laurent Descroix ${ }^{2}$ Olivier BRUneau ${ }^{2}$ Vincent BEZARD ${ }^{2}$ Jacques BEAUCHÈNE ${ }^{1}$

\section{${ }^{1}$ Cirad}

UMR ECOFOG

97310 Kourou Cedex

French Guiana

France

${ }^{2}$ Office National des Forêts (ONF) Département R\&D

Pôle de Cayenne

Réserve de Montabo

BP 87002

97307 Cayenne Cedex

French Guiana

France

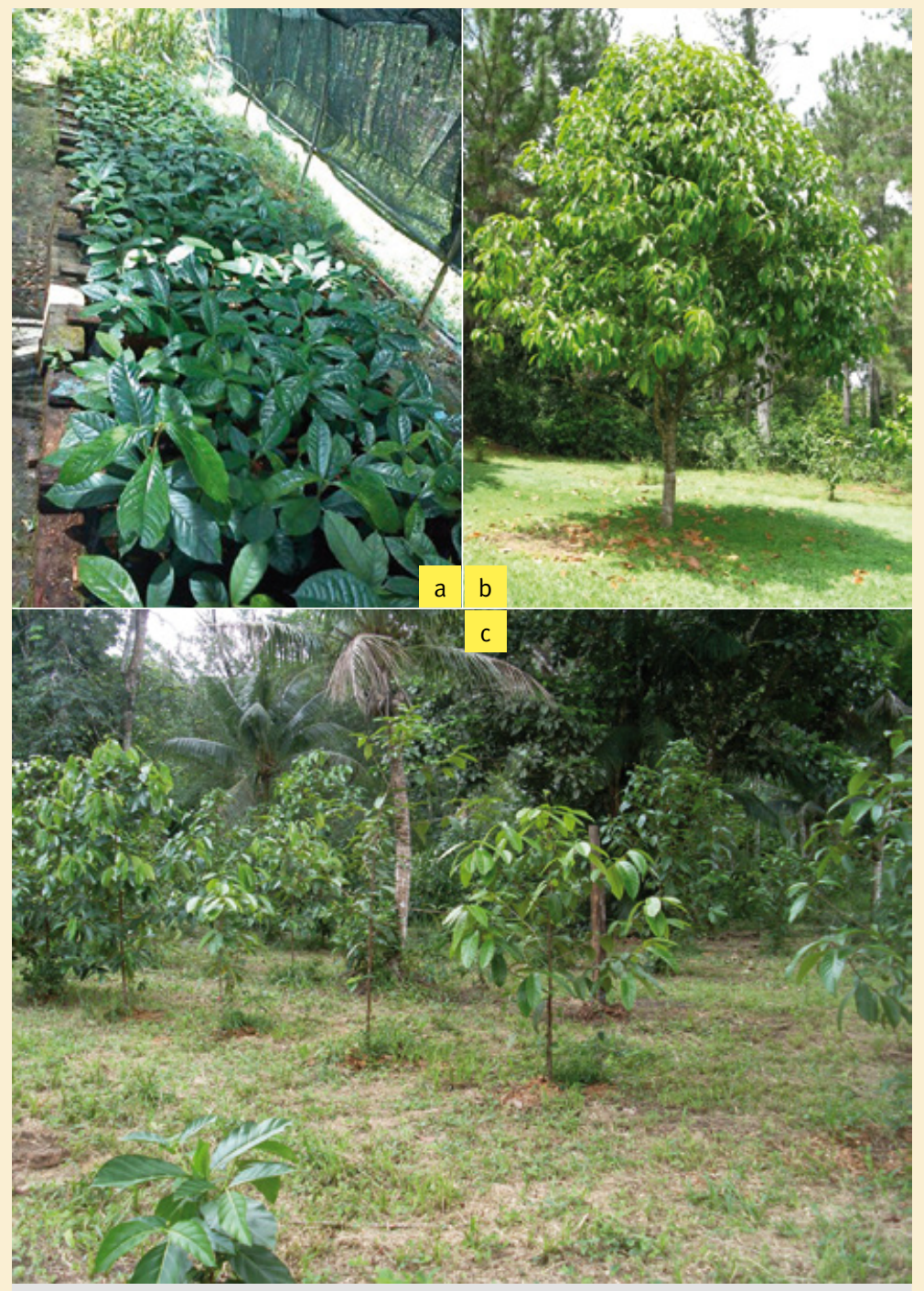

Photo 1.

Bois de rose (Aniba rosaeodora) : seedling (a), 8 years old tree (b),

2 years old plantation(c).

Photos Projet anib@rosa. 


\section{RÉSUMÉ}

\section{PLANTATION DE BOIS DE ROSE POUR LE DÉVELOPPEMENT DE LA PRODUCTION \\ D'HUILE ESSENTIELLE : INFLUENCE DU MILIEU FORESTIER ENVIRONNANT ET DE LA PROVENANCE DES GRAINES SUR LA CROISSANCE DE L'ARBRE ET LA PRODUCTION DE L'HUILE ESSENTIELLE}

L'huile essentielle de bois de rose (Aniba rosaeodora Ducke) recherchée pour ses propriétés olfactives est un ingrédient majeur de la parfumerie de luxe. En raison d'une surexploitation ces dernières décennies, le bois de rose est désormais considéré comme une espèce en voie de disparition. Envisager de produire de l'huile essentielle à partir de plantations s'avère une alternative pertinente. Nous avons planté 605 arbres de bois de rose issus de graines de deux provenances de Guyane française sur une parcelle de $5445 \mathrm{~m}^{2}$. La plantation présente la particularité d'être entourée de forêt primaire. Après une période de 9 ans, nous avons évalué l'effet de la position de l'arbre par rapport à la forêt environnante et de la provenance des graines sur les traits dendrométriques (hauteur, circonférence, biomasse ligneuse) et le rendement en huile essentielle. Les arbres présentent une croissance moyenne en hauteur de $0,7 \mathrm{~m} / \mathrm{an}$, en circonférence de $2,5 \mathrm{~cm} / \mathrm{an}$, avec une production de biomasse aérienne de $990,5 \mathrm{~kg}$ de masse sèche/ha/an. Les rendements en huile essentielle varient entre $0,6 \%$ et $3,6 \%$, avec une production moyenne de $2,1 \%$. La position de l'arbre par rapport à la forêt environnante est le principal facteur affectant la croissance des arbres et la production d'huile essentielle : les arbres situés en bordure de la forêt environnante sont significativement plus petits et accumulent moins d'huile essentielle du fait de l'influence de la disponibilité de lumière. La provenance des graines a peu d'influence sur les caractéristiques dendrométriques et le rendement en huile essentielle. En conclusion, la mise en place de plantations pourrait être un système optimal et économiquement avantageux si l'on vise la production d'huile essentielle mais il importe d'éviter les effets de bord liés à la proximité de la forêt.

Mots-clés : Aniba rosaeodora Ducke, bois de rose, plantation, huile essentielle, traits dendrométriques, effet provenance, effet lumière, Guyane française.

ABSTRACT

RESUMEN

\section{PLANTING ROSEWOOD FOR SUSTAINABLE ESSENTIAL OIL PRODUCTION: INFLUENCE OF SURROUNDING FOREST AND SEED PROVENANCE ON TREE GROWTH AND ESSENTIAL OIL YIELDS}

Essential oil from the Amazonian rosewood tree (Aniba rosaeodora Ducke) is valued as an important aromatic ingredient in luxury perfumes. Due to over-harvesting in recent decades, rosewood is now listed as an endangered species. Rosewood tree planting is now considered a viable alternative to logging as it can support both reforestation and sustainable agriculture thanks to sales of the essential oil extracted. We planted 605 rosewood trees in French Guiana from two seeds of local provenance, in a $5445 \mathrm{~m}^{2}$ plot surrounded by primary forest. Nine years after planting, we assessed the effect of the position of the tree relative to the surrounding forest and of the seed provenance on dendrometric traits (height, circumference, above ground woody biomass) and hence on the yield of essential oil. Measurements were made on 99 trees. Average growth rates for the young trees were $0.7 \mathrm{~m} /$ year in height, $2.5 \mathrm{~cm} /$ year in stem circumference and $990.5 \mathrm{~kg}$ dry mass/ha/year in aboveground biomass, while essential oil yields ranged from $0.6 \%$ to $3.6 \%$ with a mean of $2.1 \%$. The position of the tree relative to the surrounding forest was the main factor affecting tree growth and essential oil production: trees located close to the surrounding forest were significantly smaller and accumulated less essential oil due to the reduced availability of light. Seed provenance had less effect on dendrometric traits and essential oil yields. In conclusion, although planting practices will need to be adapted to avoid the edge effects of proximity to the forest, short-rotation cultivation of rosewood trees could be the optimum and most economically attractive system for the production of essential oil.

Keywords: Aniba rosaeodora Ducke, rosewood, plantation, essential oil yield, dendrometric traits, seed provenance, light effect, French Guiana.

\section{SIEMBRA DE PALO DE ROSA PARA EL DESARROLLO DE LA PRODUCCIÓN DE ACEITE ESENCIAL: INFLUENCIA DEL MEDIO FORESTAL CIRCUNDANTE $Y$ DE LA PROCEDENCIA DE LAS SEMILLAS EN EL CRECIMIENTO DEL ÁRBOL Y LA PRODUCCIÓN DE ACEITE ESENCIAL}

El aceite esencial de palo de rosa (Aniba Rosaeodora Ducke) es buscado por sus propiedades aromáticas que lo convierten en un importante ingrediente de la perfumería de lujo. Debido a la sobreexplotación de las últimas décadas, el palo de rosa está considerado actualmente como una especie en peligro de extinción. La producción de aceite esencial a partir de plantaciones supone una interesante alternativa. Se sembraron 605 árboles de palo de rosa a partir de semillas de dos procedencias de la Guayana Francesa en una parcela de $5445 \mathrm{~m}^{2}$. La plantación tiene la particularidad de estar rodeada de bosque primario. Nueve años después de la siembra, se evaluó el efecto de la posición del árbol respecto del bosque circundante y de la procedencia de las semillas en las características dendrométricas (altura, circunferencia y biomasa leñosa aérea) y el rendimiento de aceite esencial. Los árboles muestran un crecimiento promedio de

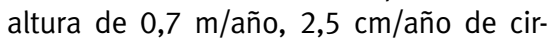
cunferencia y una producción de biomasa aérea de 990,5 kg de masa seca/ha/año. Los rendimientos de aceite esencial varían entre $0,6 \%$ y $3,6 \%$, siendo la producción promedio de $2,1 \%$. La posición del árbol respecto del bosque circundante es el principal factor que afecta al crecimiento de los árboles y a la producción de aceite esencial: los árboles ubicados en el lindero del bosque vecino son significativamente más pequeños y acumulan menos aceite debido al efecto de disponibilidad de luz. La procedencia de las semillas tuvo poca influencia en las características dendrométricas y el rendimiento de aceite esencial. En conclusión, el establecimiento de plantaciones podría suponer un sistema óptimo y económicamente interesante para la producción de aceite esencial, pero es importante evitar los efectos de borde derivados de la cercanía del bosque.

Palabras clave: Aniba rosaeodora Ducke, palo de rosa, plantación, aceite esencial, características dendrométricas, efecto de procedencia, efecto de luz, Guayana Francesa. 


\section{Introduction}

The tropical forest tree Aniba rosaeodora Ducke - Lauraceae, common name rosewood, originated in Amazonia and is highly sought after in French Guiana for its essential oil, a major ingredient of high quality perfumes and cosmetic products (Chantraine et al., 2009). Beyond its cosmetic uses, rosewood essential oil is also known for its antibacterial, antifungal, cytotoxic, antioxidant and antimutagenic properties (Giordani and Kaloustian, 2006; Nóbrega de Almeida et al., 2009; Sœur et al., 2011). Rosewood essential oil was extracted from the wood at a large scale from 1875 to 1975 in French Guiana, and trees were felled in such proportions that natural populations were significantly depleted (Bruleaux, 1989). Export of rosewood oil has undergone a long decline and since 2001, French Guiana legislation bans the cutting of this species in the natural area (French Ministerial Order 2001/04/09). Today, Brazil is the only producer of rosewood essential oil worldwide. Therefore, at Brazil's request, rosewood is now included as an endangered species in the CITES database (Convention on International Trade in Endangered Species of Wild Fauna and Flora, list II: CoP15; CITES, 2010). The risk of extinction of rosewood in its natural areas and its high economic interest underline the importance of planting rosewood trees in a way that favors optimal tree growth and the production of essential oil of constant quality. This is the context in which farmers in French Guiana plan to revive sustainable rosewood essential oil production by planting trees rather than by felling trees in natural areas. The plan is mainly based on results published by Chantraine et al., (2009), who demonstrated the exceptional quality of rosewood essential oil from French Guiana. Since 1940, different plantation systems have been tested by re-planting natural seedlings. The influence of planting density, soil quality, and light availability on tree growth has also been evaluated. Tree growth was shown to be optimal in the following soil conditions: high clay content, high macro and micronutrient content, low soil density and high total soil porosity (Leite et al., 2001). However good results were also obtained in soil conditions found in fallow and late secondary forest (Krainovic, 2011). Among the main environmental factors, light availability was shown to have the most influence in the survival, growth, and reproduction of rosewood (Barata, 2001; De Carvalho Gonçalves et al., 2005; Takeda, 2008; Useche et al., 2011). Rosewood is considered to be shade tolerant, but does require light for growth in height and diameter (Viera, 1970). On the other hand, Rosa et al. (1998) showed that juvenile trees do not tolerate full sunlight: as they reported that initial growth was poor, and many yellowing rachitic plants were observed, whereas planted under shade in a secondary forest produced a yield after four years. The same authors conducted an experiment in the region of Manicoré (Brazilian Amazonia) and found that a rate of $30 \%$ intercepted light increased the leaf area, chlorophyll concentration, and stomatal conductance, but reduced the height of the trees. In contrast, Alencar and Fernandes (1978) observed that trees planted in the open flourished and reached heights of 6-7 m with substantial foliage after six years, whereas shaded seedlings languished. In the same conditions, this species had an $80 \%$

survival index, with an average increase in height of $0.83 \mathrm{~m} /$ year, and diameter of $0.79 \mathrm{~cm} /$ year. Rosewood also grew well in partial shade in the primary forest (30\% light) on a yellow clay oxisol. With $10 \times 5 \mathrm{~m}$ spacing, in the seventh year after planting, the average increase in height was $0.75 \mathrm{~m} /$ year (Alencar and Fernandes, 1978).

The yield of essential oil ranged between $0.7 \%$ and $1.2 \%$ (g of oil per $\mathrm{g}$ of dried wood as a percentage; Santana et al., 1997; Terezo et al., 1972). Some authors have reported higher essential oil content (0.9\% to $2.6 \%)$, in young trees (diameter $<10 \mathrm{~cm}$ ) than in mature trees (Santana et al., 1997). Reports of higher yields of essential oil from young trees suggest that short rotation or commercial thinning could provide sustainable sources of essential oil. In the context of French Guiana, forest land ( $0.5-2$ ha) is traditionally cleared to produce a food crop for three years (Tsayem Demaze, 2008), produce rosewood in these conditions could be an alternative. Surrounding forest could provide shade during the first stage of tree growth according to the position of the tree in the plot. The aim of this study was to assess the influence of surrounding forest and the seed provenance on tree growth (dendrometric traits) and on the yield of essential oil to discuss the potential of production of young rosewood in these conditions.

\section{Material and method}

\section{Study site and experimental design}

French Guiana is situated in the Amazonian region between latitudes $2^{\circ}$ and $6^{\circ} \mathrm{N}$, and longitudes $51^{\circ}$ and $53^{\circ} \mathrm{W}$ and ; primary tropical rainforest, rich in biodiversity covers $96 \%$ of its area (Steege et al., 2000). Our experimental rosewood tree plantation plot is located in Macouria region at an altitude of $20 \mathrm{~m}$ asl. The climate is equatorial with a 4-month dry season (August to November) and an 8-month wet season (December to July). Mean annual precipitation is 3,200 mm and mean annual temperature is $26.8^{\circ} \mathrm{C}$ (Montsinéry weather station). The geological substrate is Galibi granite.

The experimental plot was designed to resemble a farmers's plot, i.e. a small area (here $5,445 \mathrm{~m}^{2}$ ) surrounded by primary forest, which provided the necessary shade at the beginning of plant growth. In 2002, we planted 605 rosewood trees in 35 rows with $3 \mathrm{~m} \times 3 \mathrm{~m}$ spacing, with 17 trees per row (density: 1,100 trees/ha). There were three meters between the external rows and the surrounding forest (trees height $>$ 25-30 meters). The seeds originated from two different parts of East of French Guiana, half came from Cacao (4'34'60'N;

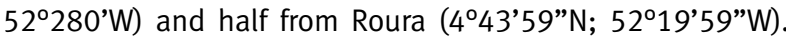
Nine years later, in 2011, 558 trees were still alive (8\% mortality rate), and thinning was implemented by removing one out of three rows of the trees. Among the cut trees, we selected 108 trees (diameter classes representative of the population) grown from seeds to measure dendrometric traits and essential oil yield. Due to the non-repeatability of essential oil yield results we eliminated 9 trees of the sampling, total trees were 99: 25 trees originating from Cacao plus 30 from Roura were situated in the middle of the plot, and 24 trees originating from Cacao plus 20 from Roura were situated close to the surrounding forest (figure 1). 


\section{Tree dendrometric traits}

We first measured the dendrometric traits of the all 99 trees: total height of the stem $(\mathrm{H}, \mathrm{m})$, stem circumference $(C, \mathrm{~cm})$ and stem diameter $(\mathrm{D}, \mathrm{cm})$ at breast height (i.e. $1.3 \mathrm{~m}$ above the ground). For each tree, we calculated the slenderness ratio $(H / D)$ which indicates tree vigor and response to competition from overtopping and encroaching vegetation (Cole and Newton 1987). The above ground biomass ( $A G B, \mathrm{~kg}$ ) of each tree was calculated using the formula $A G B=0.0509 \mathrm{\rho D}^{2} \mathrm{H}$ (Chave et al., 2005), where $\rho$ is the mean basic density calculated using the ratio of oven dried mass to green mass $(\mathrm{g} / \mathrm{cm})$. The mean basic density was measured using wood disks cut from all the trees (the sampling method is described in the following subsection). For our experiment, $\rho$ was equal to $0.47 \mathrm{~g} / \mathrm{cm}$.

\section{Extraction of essential oil}

After felling, we removed a $5 \mathrm{~cm}$ thick disk from each stem at diameter breast height as a subsample. All the bark was stripped from the discs. The subsamples were conserved at $-18^{\circ} \mathrm{C}$ until hydrodistillation. We sampled woodships from the first five centimeters (without the bark) of each wooden disc, which corresponded to the newly formed wood. The woodchips were ground (Retsch en retz ZM200 grinder with a $1 \mathrm{~mm}$ sieve). The essential oil was extracted by hydrodistillation in a Clevenger-type apparatus for three hours in $500 \mathrm{~mL}$ of water according to the method of Guenther (1972). Water was removed from the essential oil using anhydrous sodium sulfate and the oil was then weighed. The essential oil was extracted from each wood sample in duplicate. The average yield of essential oil extracted from each tree was used for further statistical analysis. The volume of essential oil harvested from each tree was calculated using AGB, assuming that most of the biomass came from the stem (Takeda, 2008).

\section{Statistics and data processing}

Descriptive statistics and Analysis of variance (ANOVA) with XLSTAT software (2013, Paris, France) was used to investigate the effect of provenance and of the position of the tree in the plot according to the surrounding forest on dendrometric traits and essential oil yield. Normal distribution of the sampling was controlled by normality test (Shapiro test). Residual variance of each model was controlled by a visual diagnosis of the square root of absolute residual against predict values and the predictors. Correlation coefficients were calculated to determine the relationship between dendrometric traits and essential oil yield. Values were considered to be statistically significant at $p<0.05$.

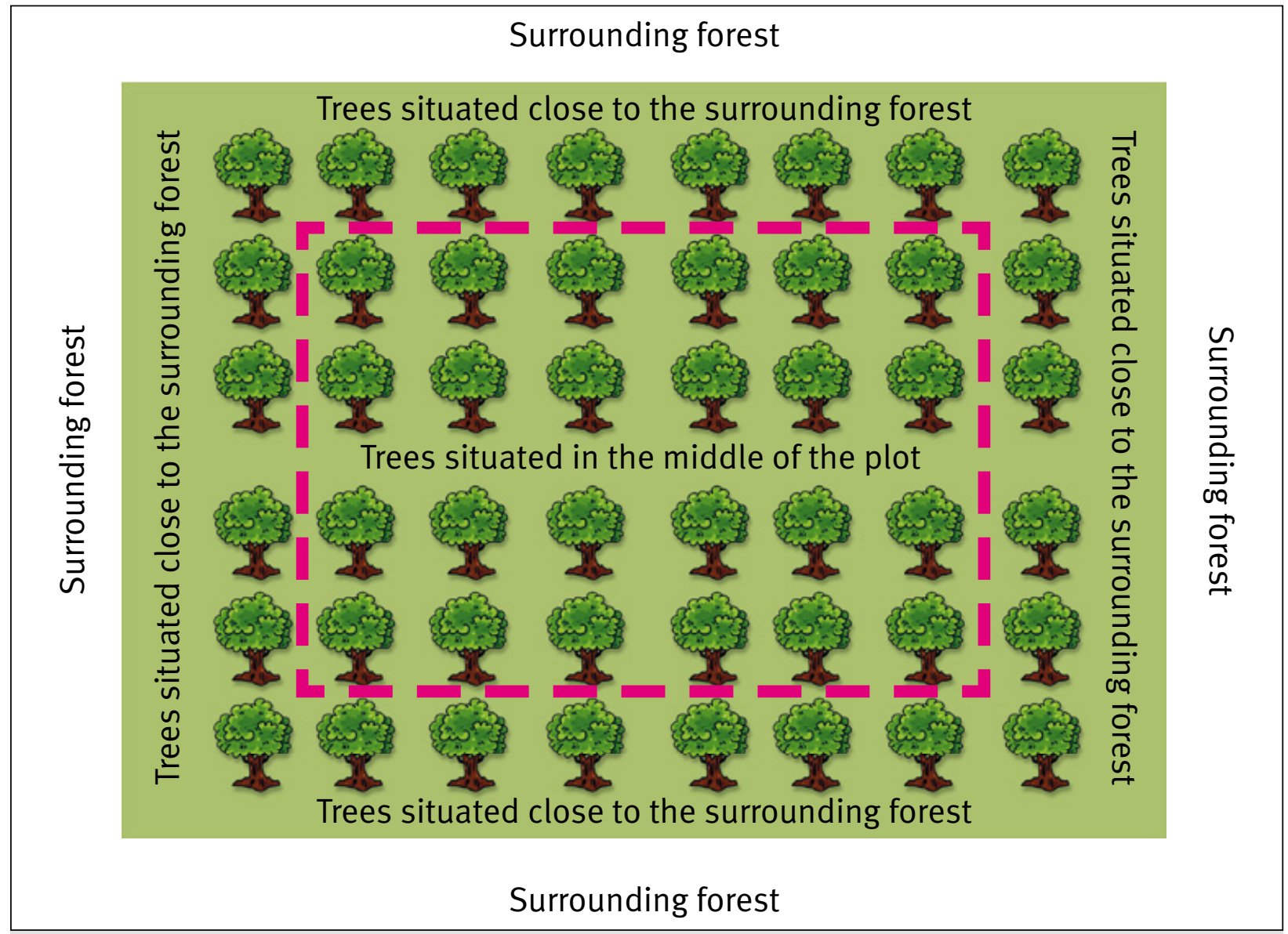

Figure 1.

Scheme of the position of the trees situated close to the surrounding forest, and trees situated in the middle of the plot 


\section{Results and discussion}

\section{Dendrometric traits}

The dendrometric traits are presented in table I and figure 2 . The mean growth of the 9 -year old rosewood trees was $0.7 \mathrm{~m} /$ year in height and $2.5 \mathrm{~cm} /$ year in circumference, which correspond to an AGB of $990.5 \mathrm{~kg} / \mathrm{ha} /$ year based on oven-dried wood (for all the trees of the plot). AGB was determined using the model of Chave (2005) with mean basic density. However, due to a possible radial and longitudinal variability of basic density in the stem, further studies will be carry out to test the influence of these parameters. The growth of our sampled trees is similar to that of trees in the same age class planted under partial shade (30\% light) in Brazil: height $0.75 \mathrm{~m} /$ year (Alencar and Fernandes, 1978). Barata (2001) reported an increase in height of $0.63 \mathrm{~m} /$ year and $0.50 \mathrm{~m} /$ year for trees in the age class planted in an open field on the Belem campus and at the Benfica site in Brazil. We also observed variability of the dendrometric traits. Stem height ranged from $2.4 \mathrm{~m}$ to $9.0 \mathrm{~m}$, stem circumference from $9 \mathrm{~cm}$ to $35 \mathrm{~cm}$, and the slenderness ratio from 45 to 140 (figure 1). Except tree effect, the position of the tree in the plot was the main factor that explained the growth of the rosewood trees: $45 \%$ of variance in circumference, $23 \%$ of total height, and $34 \%$ of tree slenderness (table I). The rosewood trees growing close to the surrounding forest, were smaller and more slender $(p<0.001)$, than trees growing in the middle of the plot. This difference is commonly observed in dominated trees with less access to sunlight due to the surrounding forest. One tree may grow faster than another if it has access to a larger supply of resources (light, water, nutrients) in the environment, or if has access to the same supply but manages to acquire a greater share than the other tree. Low intraspecific competition also increased the solar radiation intercepted by the crowns of the trees growing in the middle of the plot. Hansen et al. (1993) observed the same surrounding forest effect in a plantation of Douglas fir surrounded by an old forest in which trees growing less than $20 \mathrm{~m}$ from edge of the plot were significantly smaller and more slender than trees growing well inside the plot. Seed provenance, with a low explained variance (table II), had less impact on tree growth. Seed provenance could improve tree growth when growth conditions are not optimal. Seed from both provenances (Roura and Cacao) produced similar results in good growth conditions (trees situated in the middle of the plot) but seeds from Roura grew better $(p<0.001)$ in less favorable conditions (trees situated close to the surrounding forest). This is in line with results of other authors who emphasized the possibility of improving the growth rate by further study of genetic provenance (Barata, 2001; May and Barata, 2004).

\section{Essential oil yield}

Rosewood essential oil yield ranged from $0.6 \%$ to $3.6 \%$, mean $2.1 \% \pm 0.6$ (table I; figure 2). The great majority of the sampled trees (82.6\%) had a high yield of essential oil, i.e. more than $1.2 \%$, which several authors (Chantraine et al., 2009; Santana et al., 1997) consider to be high value for adult trees. To our knowledge, this is the first time the yield of rosewood essential oil has been evaluated in such a large sample of young planted trees. Our yields are higher than those of Ohashi et al. (1997) and Santana et al. (1997) who reported yield of essential oil ranging from $0.7 \%$ to $2.6 \%$ in young trees (diameter $<10 \mathrm{~cm}$, circumference $31 \mathrm{~cm}$ ) in Brazil.

Table I.

Mean (and standart deviation) of dendrometric traits: height $=\mathrm{H}(\mathrm{m})$, circumference $(\mathrm{cm})$, slenderness ratio $(\mathrm{H}: \mathrm{D})$, Above ground volume (AGB, kg dry wood), yield of essential oil (\% dry matter), according to the position of the tree (close to the surrounding forest vs middle of the plot);

Total AGB (kg) and essential oil (kg) for all the plot (n total $=99$ trees) - 9 years trees rosewood from French Guiana.

\begin{tabular}{|c|c|c|c|c|c|c|c|}
\hline \multirow[b]{3}{*}{ Origin of the seed } & \multirow{2}{*}{\multicolumn{3}{|c|}{$\begin{array}{l}\text { Trees situated } \\
\text { in the middle of the plot }\end{array}$}} & \multirow{2}{*}{\multicolumn{3}{|c|}{$\begin{array}{l}\text { Trees situated close to } \\
\text { the surrounding forest }\end{array}$}} & \multirow{3}{*}{ All the plot } \\
\hline & & & & & & & \\
\hline & Cacao & Roura & $\Sigma^{3}$ & Cacao & Roura & $\Sigma^{3}$ & \\
\hline Height (m) & $6.3(1.1)$ & $6.2(1.3)$ & $6.3(1.2)$ & $5.5(0.8)$ & $5.9(1.1)$ & $5.7(0.9)$ & $6.0(1.1)$ \\
\hline Slenderness ratio & $82.3(16.6)$ & $80.6(17.8)$ & $81.3(17.0)$ & $104.6(16.5)$ & 84.9 (14.0) & $95.7(18.2)$ & 87.7 (18.8) \\
\hline Circumference $(\mathrm{cm})$ & $25.3(6.7)$ & $25.3(6.8)$ & $25.3(6.7)$ & $17.0(4.1)$ & $22.1(4.7)$ & $19.3(5.0)$ & $22.7(6.6)$ \\
\hline AGB (kg) & 10.8 & 11.1 & 10.9 & 4.3 & 7.6 & 5.8 & 8.7 \\
\hline Yield EO² (\%) & $2.2(0.6)$ & $2.3(0.7)$ & $2.2(0.6)$ & $1.7(0.5)$ & $2.2(0.4)$ & $1.9(0.5)$ & $2.1(0.6)$ \\
\hline $\begin{array}{l}\mathrm{AGB}^{1}(\mathrm{~kg}) \text { of all the } \\
\text { trees of the plot }\end{array}$ & & & 604.9 & & & 256.2 & 861.2 \\
\hline $\begin{array}{l}E O^{1}(\mathrm{~kg}) \text { of all the } \\
\text { trees of the plot }\end{array}$ & & & 13.9 & & & 5.3 & 19.3 \\
\hline
\end{tabular}


These results suggest that short-rotation cultivation of trunk wood could be the optimal and economically attractive system for the production of essential oil from the stem. Because the value of the essential oil is dependent of the chemical composition, further studies are necessary to evaluate the quality of essential oil of French Guiana rosewood.
Because of the wide range of tree circumferences in our sample $(9 \mathrm{~cm}$ to $35 \mathrm{~cm})$, we analyzed the relation between tree diameter and essential oil yield. We observed that, when the effect of the tree position was not taken into account, tree circumference was positively correlated with essential oil yield $\left(p<0.001 ; R^{2}=0.31\right)$, i.e. the bigger the tree circumference,

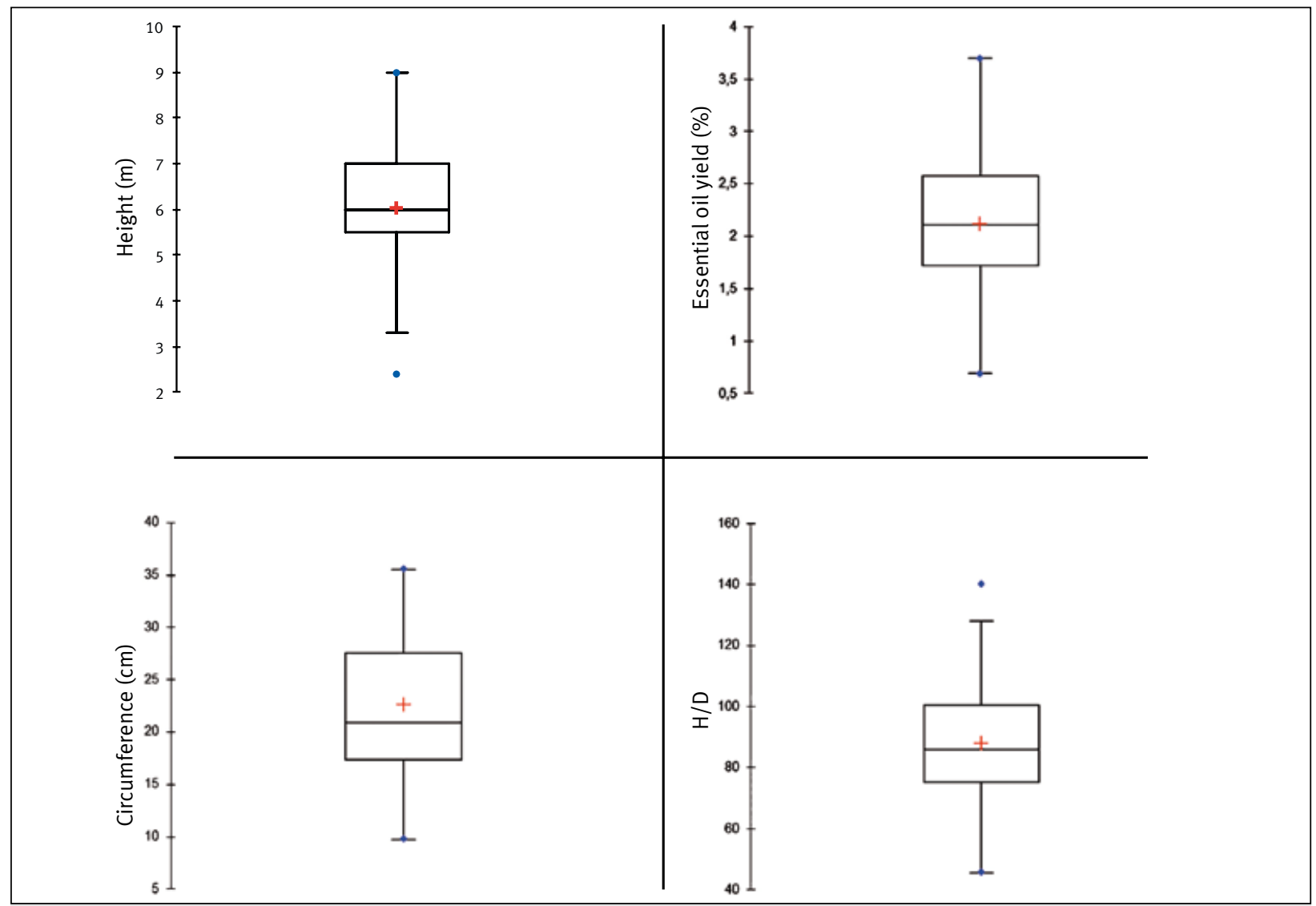

Figure 2.

Box-whisker of dendrometric traits $=H(m)$, circumference $(\mathrm{cm})$, slenderness ratio $(H: D)$, yield of essential oil (\% dry matter) - 9 year trees rosewood from French Guiana $(n=99)$.

Table II.

Summary of ANOVA table, seed effect and tree position according to the surrounding forest on dendrometric traits: height, circumference, slenderness ratio (H/D); and yield of essential oil - 9 years trees rosewood from French Guiana ( $n=99$ trees).

\begin{tabular}{|c|c|c|c|c|c|c|c|c|c|c|c|c|c|}
\hline \multirow[b]{2}{*}{ Main effects } & \multicolumn{4}{|c|}{ Height } & \multicolumn{3}{|c|}{ Circumference } & \multicolumn{3}{|c|}{ H/D } & \multicolumn{3}{|c|}{ Essential oil yield (\%) } \\
\hline & df & $\mathbf{F}$ & Pr>F & EV & $\mathbf{F}$ & Pr>F & EV & $\mathbf{F}$ & Pr>F & EV & $\mathbf{F}$ & Pr>F & EV \\
\hline Provenance effect & 1 & 0,303 & 0,583 & 0 & 3,728 & 0,057 & 1 & 8,744 & 0,004 & 10 & 3,321 & 0,072 & 6 \\
\hline $\begin{array}{l}\text { Position of the tree according } \\
\text { to the surrounding forest }\end{array}$ & 1 & 6,495 & 0,012 & 23 & 22,686 & $<0,0001$ & 45 & 16,259 & 0,000 & 34 & 5,131 & 0,026 & 16 \\
\hline $\begin{array}{l}\text { Provenance } x \text { position of the tree } \\
\text { according to surrounding effect }\end{array}$ & 1 & 0,885 & 0,349 & 23 & 4,504 & 0,036 & 46 & 7,345 & 0,008 & 44 & 3,224 & 0,076 & 22 \\
\hline
\end{tabular}

EV: explained variance (\%). 
the higher the essential oil yield (table III). But when the effect of tree position, which influenced tree growth, was taken into account, there was no longer any correlation between stem circumference and the essential oil yield of trees growing in the middle of the plot, but a weak correlation was still found in trees growing close to the surrounding forest $(p<0.1)$. This result confirms that it was the environment (i.e. the position of the tree according to the surrounding forest) that influenced the yield of essential oil rather than tree growth dynamics. Variance analysis showed that tree position explained $16 \%$ of variance ( $p<0.001)$ in essential oil yield. Trees growing in the middle of the plot had higher essential oil contents than trees growing close to the surrounding forest. These phenotypic variations were due to environmental effects, particularly light availability. The higher yield of essential oil produced by trees growing in the middle of the plot is a response to stress induced by a high level of sunlight. Sangwan et al. (2001) rightly emphasized that essential oil helps plants to adapt to environmental stresses (drought, intense radiation, and high temperature) and is also involved in defense mechanisms against pests. This hypothesis was corroborated by Manhaes et al. (2012), in Aniba canelilla (Lauraceae) a tree growing in the Amazon rainforest. These authors showed that essential oil yield of resprouts was inversely correlated with canopy openness, i.e., light increased the yield of essential oil. The same goes for herbaceous plants that are rich in essential oils: under warm sunny conditions, plants like geraniums (Pelargonium capitatum x P. radens; Weis, 1997) and Japanese mint (Mentha arvensis L.) produced higher essential oil yield or more biomass (Duriyaprapan et al., 1986).

In the present study, we showed that tree effect significantly affected the yield of essential oil (table III). Maia et al. $(2004,2007)$ suggested, there are at least four types of rosewood trees in Brazil with different morphological characteristics, whose yield of essential oil ranged from $1.8 \%$ to $3.4 \%$. Further research is thus needed to correlate oil characteristics with source material, to ensure plantation are planted with the best genetic material.

\section{Production of biomass and essential oil}

After nine years, the mean AGB was $8.6 \mathrm{~kg} / \mathrm{stem}$, and the total AGB of the 99 sampled trees was $861.2 \mathrm{~kg}$ (table I), which corresponds to a mean essential oil mass of $194.7 \mathrm{~g} /$ stem, and to a mass of $19.3 \mathrm{~kg}$ for all the harvested trees. The mean biomass and essential oil yield per tree are thus promising. Mean biomass production for the entire plot was $990.4 \mathrm{~kg}$ (dry wood)/ha/year and mean essential oil production was $22.2 \mathrm{~kg} / \mathrm{ha} /$ year. Our results support the opinion of commercial distillers in Brazil that young rosewood stems provide higher oil yields than larger mature trees (Santana et al., 1997), and we consider exploitation is feasible at 10 years of age, whereas Barata (2001), estimated that trees in an open-field plantation would require around 20 years of growth before being ready for felling and the distillation of rosewood oil. The position of the tree in the plot had a significant effect $(p<0.001)$ on biomass production and hence on the yield of essential oil and on the profitability of a plantation based on this management system. Overall stem biomass was: $1,249.5 \mathrm{~kg}$ (dry wood)/ha/year from trees situated in the middle of the plot compared to $680.5 \mathrm{~kg}$ (dry wood)/ha/year from trees situated close to the surrounding forest. Overall yield of essential oil was: $28.8 \mathrm{~kg} / \mathrm{ha} / \mathrm{year}$ for trees situated in the middle of the plot compared to $14.3 \mathrm{~kg} /$ ha/year from trees situated close to the surrounding forest. In other words, twice as much biomass and essential oil (604.9 kg dry wood and $13.9 \mathrm{~kg}$ of essential oil) was collected from 99 trees collected in the middle of the plot compared to trees collected at the edge of the plot $(256.2 \mathrm{~kg}$ dry wood and $5.3 \mathrm{~kg}$ of essential oil).

Table III.

Pearson correlations between dendrometric traits and yield of essential oil of - 9 years trees rosewood from French Guiana according the position of the trees related to the surrounding forest (middle of the plot, close to the surrounding forest) and in all the plot.

Variables

Total height (m)

Circumference $(\mathrm{cm})$

Slenderness ratio

Total height (m)

Circumference $(\mathrm{cm})$

Slenderness ratio

Total height (m)

Circumference $(\mathrm{cm})$

Slenderness ratio
Tree position

All 99 trees

55 trees in the middle of the plot

44 trees close to the surrounding forest
Yield of essential oil (\%)

$0.32^{\star \star \star}$

$0.31^{\star \star \star}$

$-0.08 \mathrm{~ns}$

0.28 *

$0.17 \mathrm{~ns}$

$-0.001 \mathrm{~ns}$

$0.28 \mathrm{~ns}$

$0.39^{\star \star}$

$-0.24 \mathrm{~ns}$

ns: not significant; ${ }^{*}$ : significant at $p<0.1 ;{ }^{* *}$ : significant at $p<0.05 ;{ }^{* \star *}$ : highly significant at $p<0.001$. 


\section{Potential for changing fallow to agroforestry by planting rosewood trees}

In the specific context of French Guiana, where there is a need to develop sustainable farming systems, our results showed that traditional forest fallow plots can be profitably converted into rosewood (Aniba rosaeodora) planting areas. But, as plots are usually small ( 0.5 to $2 \mathrm{ha}$ ), management practices need to be adapted to minimize the negative effect of the surrounding forested area on the production of biomass and of essential oil by trees planted close to the surrounding forest. In our case study, 0.5 ha plot meant the same number of trees grew in the middle of the plot as close to the surrounding forest resulting in high variability of essential oil and biomass production. To optimize the production of biomass and essential oil it would be useful to i) use bigger areas to plant rosewood trees, and ii) to create a sufficiently wide buffer zone between the rosewood plantation and the surrounding forest to avoid the surrounding effect forest. These results provide the first data to help decision makers and farmers in French Guiana who plan to revive sustainable rosewood oil production based on plantations rather than on felling trees in natural areas. Since the rosewood tree is an endangered species, our results show that plantations could be a sustainable way to protect the species while at the same time producing its sought-after essential oil. However more research is needed to link the characteristics of the essential oil with the source of the material to ensure that plantations are planted with the best genetic material possible.

\section{Conclusion}

The overall aim of this study was to explore the commercial potential of young rosewood trees in a plantation located in a primary forest by assessing the effect of the surrounding forest and of the provenance of the seed on dendrometric traits of trees and hence on the yield of essential oil. After nine years of growth, the mean growth of trees was $6.0 \mathrm{~m}$ in total height and $22.7 \mathrm{~cm}$ in circumference with a high yield of essential oil (2.1\%). Trees growing close to the surrounding forest were smaller with lower essential oil yield than trees growing in the middle of the plot due to the availability of light. Seed provenance had less effect on dendrometric traits and on essential oil yield. The results of our study show that, thanks to their high potential for biomass production and high yield of essential oil, young rosewood trees felled during thinning operations could be exploited commercially or dedicated plots could be used for short rotations. A better understanding of the surrounding forest effect on tree growth and essential oil yield is likely to help forest managers to design plantations that best achieve goals for productivity. This management system would not only protect an endangered species but also provide a sustainable source of rosewood trees for the production of essential oil.

\section{Acknowledgments}

This study was conducted in the framework of the project Anib@rosa (Contribution à une gestion durable du bois de rose) funded by the European Regional Development Funds (FEDER) for French Guiana: agreement number 31033.

\section{Bibliographical references}

Alencar J. C., Fernandes N. P., 1978. Desenvolvimento de árvores nativas em ensaios de espécies. 1. Pau rosa (Aniba duckei Kostermans). Acta Amazônica, 8(4): 523-541.

Barata L. E., 2001. Brazilian rosewood: the potential for plantations and for the production of leaf oil. International Conference in Buenos Aires, Argentina, November 2001, p. 69-76.

Binkley D., Stape J. L., Bauerle W. L., Ryan M. G., 2010. Explaining growth of individual trees: light interception and efficiency of light use by Eucalyptus at four sites in Brazil. Forest Ecology and Management, 259: 1704-1713.

Bruleaux A. M., 1989. Deux productions passées de la forêt guyanaise: l'essence de bois de rose et la gomme de balata. Bois et Forêts des Tropiques. 219: 99-113. [En ligne] http:// bft.cirad.fr/cd/BFT 219 99-113.pdf

Chave J., Andalo C., Brown S., Cairns M. A., Chambers J. Q., Eamus D., et al., 2005. Tree allometry and improved estimation of carbon stocks and balance in tropical forests. Oecologia, 147: 87-99.

Chantraine J. M., Dhenin J. M., Moretti M., 2009. Chemical variability of Rosewood (Aniba rosaeodora Ducke) essential oil in French Guiana. Journal of Essential Oil Research, 21 (6): 486-495.

CITES, 2010. Quinzième session de la Conférence des Parties (CoP15 Prop. 29) - Doha (Qatar), 13-25 mars 2010. [Online] http://www.cites.org/fra/cop/15/prop/F-15\%20Prop-29.pdf

Cole E. C., Newton M., 1987. Fifth-year responses of Douglas-fir to crowding and non-coniferous competition. Revue canadienne de recherche forestière, 17(2): 181-186.

De Carvalho Gonçalves J. F., Caranhas de Souza Barrreto D., Moreira dos Santos Junior U., Varmes Fernandes A., Barbosa Sampaio P. T., Silveira Buckeridge M., 2005. Growth, photosynthesis and stress indicators in young rosewood plants (Aniba rosaeodora Ducke) under different light intensities. Brazilian Journal of Plant Physiology, 17(3): 325-334.

Duriyaprapan S., Britten E. J., Basford K. E., 1986. The effect of temperature on growth, oil yield and oil quality of Japanese mint. Ann. Bot, 58(5): 729-736.

Giordani R., Kaloustian J., 2006. Action anticandidosique des huiles essentielles: leur utilisation concomitante avec des médicaments antifongiques. Phytothérapie, 3: 121-124.

Guenther E., 1972. The production of essential oils. In: E. Guenther (ed.), The essential oils. Krieger Publ. Co., Malabar, FL, USA, p. 87. 
Hansen A. J., Garman S. L., Lee P., Horvath E., 1993. Do edge effects influence tree growth rates in Douglas-fir plantations. Northwest sciences, 67(2): 112-116.

Krainovic P. M., 2011. Plantios de Pau rosa (Aniba rosaeodora Ducke) estabelicidos em areas com historicao de uso por atividades agricolas e pecuarias. Manaus Amazona. Abril 2011. Dissertação apresentada ao Programa de Pós-Graduação em Ciências de Florestas Tropicais, do Instituto de Pesquisas da Amazônia, como parte dos requisitos para obtenção do título de Mestre em Ciências de Florestas Tropicais área de concentração em silvicultura Tropical.

Leite A. M. C., Caetano Quisen R., Sampaio P. T. B., 2001. Pau-rosa (Aniba rosaeodora Ducke) Lauraceae): Informações sobre o Sistema de Plantio e o Manejo Sustentável da Espécie. Embrapa.

Maia J. G. S., Andrade E. H. A., Couto H. A. R., Da Silva C. A. M., Marx F., Henke C., 2007. Plant sources of rosewood oil. Quím Nova, 30 (8): 1906-1910.

Maia N. B., Bovi O. A., Perecin M. B., Marques M. O. M., Granja N. P., 2004. Newcrops with potential to produce essential oil with high linalool content helping preserved rosewood - an endangered Amazonian species. Acta Horticulturae, 629.

Manhaes A. P., Veiga-Junio V. F., Moreira Wiedemann L. S., Fernandes K. S., Sampaio P. T. B., 2012. Biomass production and essential oil yield from leaves, fine stems and resprouts using pruning the crown of Aniba canelilla (H.B.K.) (Lauraceae) in the Central Amazon. Acta Amazonica, 42(3): 355-362.

May P., Barata L. E. S., 2004. Rosewood exploitation in the Brazilian Amazon: options for sustainable production. Economic Botany, 58(2): 257-265.

Nóbrega de Almeida R., Araujo A. M. M., Gonçalves J. C. R., Montenegro F. C., Pergentino de Sousa D., Leite J. R., Mattei R., Benedito M. A. C., Barbosa de Carvalho J. G. B., Cruz J. S., Maia J. G. S., 2009. Rosewood oil induces sedation and inhibits compound action potential in rodents. Journal of Ethnopharmacology, 124: 440-443

Ohashi S. T., Rosa J. A., Santana J. A., Green C. L., 1997. Brazilian rosewood: sustainable production and oil quality management. Perfumer and Flavorist, 22: 1-5.

Rosa L. dos S., Sa T. D. A., De Carvalho C. J., Malheiros M. A. de B., Dias M. L. Da S., 1998. Respostas ecofisiológicas e morfológicas do pau-rosa (Aniba rosaeodora Ducke) aos diferentes níveis de sombreamento, em condição de viveiro. Boletim da Facultade de Ciencias Agarias do Pará, Belém, PA, 301:19-132.
Santana A., Oashi L., De Rosa A., Green C. L., 1997. Brazilian rosewood oil. The project for sustainable production and oil quality management. International Journal of Aromatherapy, 8(3): 16-20.

Sangwan N. S., Farooqi A. H. A., Shabih F., Sangwan R. S., 2001. Regulation of essential oil production in plants. Plant Growth Regulation, 34(1): 3-21.

Sœur J., Marrot L., Perez P., Iraqui I., Kienda G., Dardalhon M., Meunier J. R., Averbeck D., Huang M. E., 2011. Selective cytotoxicity of Aniba rosaeodora essential oil towards epidermoid cells through induction of apoptosis. Mutation Research, 718: 24-32.

Steege H., Sabatier D., Castellanos H., Van Andel T., Duivenvoorden J., De Oliveira A. A. EK R., Lilwah R., Maas P., Mori S., 2000. An analysis of the floristic composition and diversity of Amazonian forests including those of the Guiana Shield. Journal of Tropical Ecology, 16(6): 801-828.

Takeda P. S., 2008. Valiação de biomassa e óleo de rebrotas de galhos e folhas de pau-rosa (Aniba rosaeodora Ducke) em plantios comerciais submetidos à poda e adubação. Tesis de Maestria (Ciencias de Florestas Tropicales). Instituto Nacional de Pesquisas da Amazônia / Universidade Federal do Amazonas. Manaus, Amazonas, 73p.

Terezo F. E. de M., De Araújo V. C., De Araujo V. F., Do Nascimento V. F., Souza J. da C., 1972. O extravisimo do pau-rosa (Aniba duckei Kosterm., Aniba rosaedora Ducke). Sudam, Doc. Amaz. Belém, 3(1/4): 5-55.

Tsayem Demaze M., 2008. Croissance démographique, pression foncière et insertion territoriale par les abattis en Guyane française. Norois, 206 (1) : 111-127.

Useche F. L., Valencia W. H., Viera G., 2011. Desarrollo inicial de Aniba rosaeodora Ducke en claros artificiales de bosque primario Amazonia central brasilera. Ingenierías \& Amazonia, 4(1): 5-18.

Viera A. N., 1970. Aspectos silviculturais do pau-rosa (Aniba rosaeodora duckei Kostermans) II. Estudos sobre métodos de propagação. Acta Amazonica, 2 (1): 51-58.

Weiss E. A., 1997. Essential oil crops. New York and Wallingford: Centre for Agriculture and Biosciences (CAB) International. 